\title{
Household financial planning with financial advisory assistance
}

\author{
ŁUKASZ MACIEJ Mitek \\ mgr, Uniwersytet Szczeciński, Wydział Zarządzania i Ekonomiki Usług \\ e-mail:1mitek@o2.pl.
}

ABSTRACT In the article there are described definitions of a household and of financial advisory services, as well as the concept of household financial planning with assistance of a financial advisor. Additionally, an overview of financial advisors' fields of expertise has been presented, as well as wide scope of services they provide. Moreover, the role of financial advisors in the process of making financial decisions by household members has been established and presented on a simple model:

Purpose - the aim of the article is to present financial advisory services and the importance of financial planners in the process of household financial planning.

Methodology - critical analysis of source literature, document study, method of logical analysis.

Findings - the author points out the advantages of involving financial advisor in the process of financial planning and shows the changes that are occurring on financial market which presuppose this process.

Value - taking into account limited publications in the financial advisory field, I asses the article uniqueness value as medium.

\section{Planowanie finansów gospodarstw domowych z doradztwem finansowym}

Stowa kluczowe doradztwo finansowe, finanse gospodarstw domowych, planowanie finansów gospodarstw domowych

ABStRAKT W artykule przedstawiono pojęcie gospodarstwa domowego oraz doradztwa finansowego, a także koncepcję planowania finansów gospodarstw domowych z udziałem doradców finansowych. Dodatkowo wskazano obszary działalności doradców finansowych oraz szereg usług finansowych przez nich świadczonych. Ponadto umiejscowiono rolę doradców finansowych w procesie podejmowania decyzji finansowych przez członków gospodarstw domowych na przykładzie prostego modelu.

Cel-artykuł ma na celu przedstawienie branży doradztwa finansowego i znaczenia doradców finansowych w procesie planowania finansów gospodarstw domowych.

Metodyka badania - krytyczna analiza literatury przedmiotu, metoda badań dokumentów, metoda analizy logicznej.

Wynik - w artykule wskazano korzyści wynikające z udziału doradcy finansowego w procesie planowania finansowego oraz zmiany zachodzące na rynku finansowym, które ten proces implikują.

Wartość - z uwagi na niewielką ilość publikacji z zakresu doradztwa finansowego oryginalność oceniam jako średnią. 


\section{Introduction}

In today's world, members of household have greater than ever access to a wide range of products, allowing them to obtain resources and secure their capital for the future. Changes occurring on the financial services market imply the consumer demand for quality advisory services. Therefore, along with the development of financial services available on capital market, members of household and supervisory institutions pay increased attention to adjusting the presented financial solutions to expectations and financial literacy of individual household members. The aim of the article is to present financial advisory services and the importance of financial planners in the process of household financial planning. It is widely considered that financial advisor should bear practical ability to use financial instruments and have high interpersonal communication skills. It is the level of professional expertise of the advisor that determines if the proposed solutions will be sufficient to satisfy financial needs of the household.

\section{The definition and characteristics of financial advisory services}

Counseling has always been a very important part of human life. It enabled us to crystalize our own experiences and thoughts, develop personal skills and to make more informed decisions and choices. As Ciechanowicz (2010, p. 50) suggests, first mentions of the subject lead back to Egyptian priests, who were advising pharaohs and had great influence on their decisions. He also mentions ancient philosophers, who established the theory of counseling in many different areas. According to Waliszewski (2011, pp. 100-101), the breakthrough in advisory services development came in $19^{\text {th }}$ century, when - during the Industrial Revolution - congeneric changes in technical, economic and social models occurred. It was then that a new model of organization management arose and it made a great impact on the industry in the United States, becoming a scientific fundament for future advisors. As Brandon and Welsh (2009, pp. 3-8) suggest, the ground for professional financial planning has been laid during the meeting of Loren Dunton and James R. Johnson in Chicago in December 1969. It was then established that any person who takes up household financial consulting should not only abide by the law and bear high ethical standards, but also acquire appropriate certification to document their competencies.

Financial planning from its very beginning has been recognized as a dynamically evolving segment of the financial services market. In their papers, Korenik (2006, p. 38) and Waliszewski (2012, p. 482) define financial planning as chargeable economic activity or unpaid service provided by dependant advisors, which consists of giving customers and potential customers reliable information about available financial solutions (investments, loans and insurances) related to various aspects of household activities, which leads to making optimal financial decision or achieving desired result by creating financial plans and managing private accounting liquidity.

According to Skorwider (2011, p. 271), the household demand for financial services can be supplied by various units of financial market. Financial planning services are supplied by private enterprises, as well as individuals employed by one of numerous financial institutions. As Arthur (2012, p. 11) suggests, it is commonly regarded that mainly financially conscious consumers will be able to fully utilize modern financial products, as they are able to choose the compounds that are tailored to their needs and financial awareness, which allows them to receive signals 
from financial markets and react accordingly. Yet, the newest research on economic education in chosen research facilities (Tullio, Mario, 2011), including studies of OECD (Atkinson, Messy, 2012) and FL World (Lusardi, Mitchell, 2011; Agnew et al., 2013) project, show overall low level of financial literacy. Stiftung (2014, p. 23) concludes that, in consequence, it may result in incorrect reactions in household financial planning. Therefore, as Jajuga (2008, p. 390) suggests, the importance of financial advisory services in household financial planning rises, and the basis for the development of this profession - except for the already mentioned lack of appropriate knowledge in households - lies in economic well-being of certain groups of society. That implies the necessity to research new investment opportunities and to develop new financial instruments, which requires professional expertise on the level of individual investors. Moreover, lack of time to conduct detailed financial analysis and large variety of financial instruments impose the need for specialization.

Table 1. Chosen areas of household financial planning, including financial advisory area

\begin{tabular}{|l|l|l|}
\hline \multicolumn{1}{|c|}{ Area } & \multicolumn{1}{|c|}{ Area description } & \multicolumn{1}{c|}{ Advisory area } \\
\hline $\begin{array}{l}\text { Cash flow } \\
\text { planning }\end{array}$ & $\begin{array}{l}\text { planning of current financial liquidity of a household, i.e. ability to regulate } \\
\text { financial liabilities by its members by designing a time structure of household } \\
\text { cash flow in a way that services current debt to current income }\end{array}$ & $\begin{array}{l}\text { financial liquidity } \\
\text { maintenance } \\
\text { counselling }\end{array}$ \\
\hline $\begin{array}{l}\text { Investment } \\
\text { planning } \\
\text { and wealth } \\
\text { management }\end{array}$ & $\begin{array}{l}\text { planning of long-term investments, which value is strictly dependant on reliable } \\
\text { household budget report and financial balance sheet reports; when making } \\
\text { a decision, investor should consider the following: return (yield, profitability), } \\
\text { market liquidity and risk }\end{array}$ & $\begin{array}{l}\text { consulting, } \\
\text { financial consulting }\end{array}$ \\
\hline $\begin{array}{l}\text { Gaining } \\
\text { capital and } \\
\text { liability } \\
\text { management }\end{array}$ & $\begin{array}{l}\text { widely understood liability management by making decisions involving } \\
\text { acquiring resources to achieve objectives, i.e. via consumer credits and } \\
\text { mortgage loans as well as decisions about current liabilities, i.e. debt } \\
\text { consolidation or household financial stability }\end{array}$ & $\begin{array}{l}\text { credit consulting, } \\
\text { financial consulting }\end{array}$ \\
\hline $\begin{array}{l}\text { Health and } \\
\text { life insurance, } \\
\text { property guard }\end{array}$ & $\begin{array}{l}\text { planning consisting of transfer of risk by purchasing a variety of insurance } \\
\text { products in order to secure assets, health and life of household members, risk } \\
\text { management }\end{array}$ & $\begin{array}{l}\text { insurance } \\
\text { consulting, } \\
\text { financial consulting }\end{array}$ \\
\hline $\begin{array}{l}\text { Old age } \\
\text { security }\end{array}$ & $\begin{array}{l}\text { making decisions about long-term systematic savings attributed to retirement } \\
\text { income protection; the main objective in this area is to create retirement capital }\end{array}$ & $\begin{array}{l}\text { retirement } \\
\text { consulting, } \\
\text { financial consulting }\end{array}$ \\
\hline
\end{tabular}

Source: own elaboration based on Waliszewski (2011), p. 38.

Taking into account the changes occurring in financial services market that imply the customer's expectations of financial planners, one may conclude that financial advisor needs to have practical skills in operating various financial instruments and interpersonal skills to be able to communicate with clients. The objective of a financial planner is to take the finances of a household as a whole, not only specific parts of it, considering that realization of financial plans of their customers' depends on the analysis of their needs and the possibilities they have to satisfy them, as well as showing them alternative solutions that are a part of financial planning. The primary tools for household financial planning include creating a financial plan, balance sheet and financial flow statement. 


\section{The definition and characteristics of household finances and the decision process}

In the traditional theory of economy, household is often associated with terms such as family or home, thereupon to define and crystallize this term will involve finding precise criteria. that would allow to distinguish it from other terms.

As Drabik and Smyczek suggest (2007, pp. 45-46), a household is a relatively fixed unit which prospers for the purpose of consumption and within consumption area. It cultivates household economy, which consists of income management. The distinguishing factor of being a household member is common residence and joint income management, spending decisions and administration of assets.

Complex nature of household reflects in terminology. The source literature shows at least a few common features of household: family bonds, common assets, common residence, aiming to satisfy both individual and collective consumer needs, as well as managing household budget and sharing the costs of its operations.

Undoubtedly one of the fundamental elements of market economy is finance, which - as a scientific discipline - includes statements and theories involving the means of gaining, creating and storing financial assets. Household finance on the other hand, is scientific subdiscipline, which in both Polish and foreign literature is often interchangeably described by various equivalent or synonymous concepts.

As Campbell (2006, pp. 1553-1604) suggests, household finance, as well as enterprise finance, researches how households/enterprises achieve their goals with use of financial instruments. Bywalec (2009, p. 139), however, concludes that household finance is a set of economic phenomena occurring within households, which are strictly associated to accumulating and expending financial assets by households. According to Korenik (2006, p. 22), preferences of households in the financial field become apparent in two ways:

1. Individual - spendings on the score of tangible goods or on financial market, that are creating productive demand and are reflecting in supply economy.

2. Social - each consumer that runs a household is a taxpayer and is therefore expecting that certain public goods will be supplied by social and legal entities.

As stated by Świecka (2009, p. 36), one of the areas of financial decisions in households is consumption, which in general is understood as satisfying human needs as part of a complex process. The desirable level of consumption in household sector is dependant on both personal income, which may come from various sources, and spending of local and central government institutions, as well as non-commerce institutions that are acting in favor of households. Other variables that are influencing the consumption levels are choices made by members of households. These are dependant on the nature of subject of choice, financial limitations and individual preference along with socioeconomic status.

In line with the classical theory of economy, the pillars of household development are decisions made about the level and course of education, career path and way of spending the income. Each household is aiming for expending their income in such manner, which - taking into account their preferences - will allow them to achieve the highest possible level of utility from purchased goods and services, and the decision-making process is influenced by subjective factors, such as 
law, tradition and routines, as well as objective ones, i.e. the level of income and market pricing. The results of decisions taken by households are, on one hand, a specific demand for goods and services, and on the other - the size and structure of the supply. The rationality of human behavior is identified with the principle of rational management, according to which a household either makes decisions that will result in the best possible outcome using their current resources (the principle of efficiency), or in achieving desired outcome with minimal resources (the principle of equity). Zaleśkiewicz (2012, p. 57) concludes that the theory of rational economic decisions faces people with very strict requirements. When forming judgment or making a choice, the subject needs to analyze all available information and only rely on those that are objectively the most important. During the decision-making process, they may encounter major disadvantages or struggle with their own cognitive limitations, and the effects of their wrong decisions will impact their household finances.

As Wilkinson (2008) and Zaleśkiewicz (2012, pp. 21-27) suggest, the concept of rational behavior is based on the following premises:

1. Households assess and make economic decisions rationally.

2. When making a decision, households maximize expected benefits.

3. Households are motivated by egotistical objectives and ignore outcomes of other participants of an economic interaction.

4. Households rationally calculate probability.

5. Households show fixed preferences when making a decision with delayed effects.

6. All sources of income are fungible.

According to Harrison (1995, pp. 2-7) and Robbins (2005, p. 21), the process of making rational financial decisions is conducted by analysis of problem situation, finding possible solutions, assessment of these solutions and choosing the best one, as well as implementing the decision and following the results. During the aforementioned stages, the perfect decision-maker analyzes the household decisional area (e.g. time-consuming commuting by public transport), finds best possible solutions (e.g. purchase of a vehicle, changing the workplace, moving to another apartment), makes a decision and implements it, and later monitors the outcome.

As Bodie and Merton (2003, p. 26) suggest, households make four types of financial decisions:

1. Decisions on consumption and savings (How much resources should be spent on consumption and what portion of income should go towards savings?).

2. Investment decisions (How the savings should be invested?).

3. Debt decisions (When and how households should make use of other people's assets to implement their consumption and investment plans?).

4. Decisions connected to risk management (How and on what circumstances households should look for possibilities of reducing financial uncertainty and when should they decide to increase the risk?).

In the theory of economy there are various definitions of management given. In management practice, certain routine elements of management process have crystallized, creating one logical structure. They are often called management functions, and can also be used in reference to household financial management. They consist of planning, organizing, motivating and controlling. 
As Nowak (1995, p. 138) states, planning is a process which includes systematic evaluation of course of action and utilizing resources in order to reach intended goals. What is more, according to Komorowski (2001, p. 12), planning shows certain general qualities: it pertains to the future, requires forecasting and a will to act, and is connected to decision-making process. Bywalec (2009, p. 45) concludes that household financial planning is the entirety of actions taken by household members, that involve obtaining and spending resources in accordance with objectives set by the household. Jajuga (2008, p. 390), however, claims that it is a process of planning consumption spending, investments and obtaining (financial) assets in order to optimize economic conditions of a person or a household.

Undoubtedly financial planning is a specific decisional process, that is conducted to achieve particular objectives. The decisions made may differ, depending on the subject (legal person, legal entity) that sets the objectives, however they will be based on analysis of methods used, as well as available financial instruments and tools.

\section{The role of financial planners in planning household finance}

As Hens and Bachmann (2010, p. 31) suggest, it is widely considered that household members usually do not act in optimal way and that there is a descriptive/realistic approach, which aims to characterize their actual behaviors. According to Khaneman and Tversky's (2000), psychological research on making decisions in a state of uncertainty, personal preferences tend to skew in the face of a risk, and one of the contributing factors is the use of simple heuristics by financial advisors, clients and investors that may influence their financial decisions. Therefore, as Hens and Bachmann (2010, pp. 24-25) suggest, what makes a very important part of each model of financial consulting is full analysis of preferences and financial behaviors of the client, which has been described in many studies (see Zaleśkiewicz, 2012; Tyszka, 2010) on investors' preferences and financial decisions made by them.

The Behavioral Life-Cycle Hypothesis states that due to lack of self-control, households reluctantly give up on consumption or mobilize funds for retirement. As Shefrin and Thaler (1988, p. 609) note, households show sentiment to spread their assets between three mental accounts: 1) income for current spendings; 2) current assets and 3) future income. According to this theory, the consumption will first occur from: 1) current income, then when finances on this account are spent entirely, the consumption moves to 2) second account, analogous process takes place with 3 ) the future income account. Taking into account the marginal propensity to consume as well as marginal propensity to save and the life-cycle of households, financial advisor should propose solutions that will be adequate for each and all of the members.

Therefore the role of the advisor and the main objective of financial planning is a longterm analysis of financial needs and choosing optimal solutions to satisfy individual needs of household members. Financial planning in households consists of adjusting a variety of financial instruments to the dynamic situation of household, in order to find solutions that will be optimal on each stage of the life-cycle.

According to Waliszewski (2011, p. 153), the process of financial planning with advisory assistance consists of the following stages: 
1. Analysis of the financial situation by identifying changes in economic needs as well as objectives and products employed thus far by household members. Advisor conducts a test of capital adequacy and assesses the investment profile.

2. Concept - or modification of existing concept - of appropriate set of financial products for the household. It is developed individually by financial advisor, who may consult proposed solutions with advisory partnership team of specialists.

3. Implementation, i.e. modifying the concept by presenting financial solutions which will satisfy household needs, and conducting all transactions that are necessary to apply the chosen solution.

4. Control, which consists of monitoring the market and the financial concept of household. During meetings with household members, advisor modifies the current financial strategy to be able to best respond to variable needs and market situation.

Independent financial advisors are most likely to develop all of the abovementioned stages themselves, while advisors associated with financial institutions are using standardized process and the advisor himself or herself can devote more time to developing relationship and analyzing customer's needs. Primarily, financial planners should be aware of which needs are characteristic for each of the stages of household members' life-cycle. One of the simplest mechanisms used to achieve this is customer segmentation. Customers belonging to specific segment are a part of homogeneous group, which is characterized by similar needs and expectations towards services offered by their advisor. Most economic models are based on assumption that household preferences have no correlation to their acquired assets. According to Hens and Bachmann (2010, p. 143), in order to fully understand individual needs of household members, advisor should essentially analyze in detail all of the factors that determine preferences and motives involved in making financial decisions. The knowledge about turning points - such as university graduation, marriage, having children or retirement - that determine entering the next stage of life-cycle is crucial.

Only after the analysis the development of financial concept may begin - it consists in assets and liabilities management of the household. Correctly chosen concept involves optimal allocation of resources in various classes of assets. Its development starts with creating an investor profile for each household member and assessment of investment probability that will take into account the defined risk to return balance. Next stages consist of implementing the chosen investment strategy and monitoring the changes occurring within the household (change of lifecycle stage or investor profile).

Table 2. Household financial planning including various life-cycle stages of its members

\begin{tabular}{|l|l|l|l|l|}
\hline \multicolumn{1}{|c|}{ Early career } & Marriage and family & \multicolumn{1}{c|}{ Investment stage } & \multicolumn{1}{c|}{ Property stage } & \multicolumn{1}{c|}{ Retirement } \\
\hline $\begin{array}{l}\text { Personal } \\
\text { education, } \\
\text { basic coverage } \\
\text { and financing } \\
\text { spendings }\end{array}$ & $\begin{array}{l}\text { Financial security for } \\
\text { the family, financing } \\
\text { the purchase of } \\
\text { property, liability } \\
\text { management }\end{array}$ & $\begin{array}{l}\text { Providing education } \\
\text { to children, retirement } \\
\text { investment and } \\
\text { allocation of resources } \\
\text { into various assets }\end{array}$ & $\begin{array}{l}\text { Investing capital } \\
\text { surplus: } \\
- \text { intermediate } \\
\text { investments } \\
\text { long-term } \\
\text { investments }\end{array}$ & $\begin{array}{l}\text { Elimination of risks } \\
\text { and distribution of } \\
\text { wealth: travelling, } \\
\text { medical care, } \\
\text { inheritance/gift by will, } \\
\text { succession }\end{array}$ \\
\hline
\end{tabular}

Source: own elaboration based on: Siegel (2010), p. 314; Xelion..., (2005). 
In countries where financial planning is well developed, the range of services provided by advisors and financial institutions spreads beyond just household financial planning, and applies also to legal, tax and effects management as well as family life planning (family office, lifestyle management). This process is a part of financial planning, where household is the recipient, whereas financial plan (personal budget) is one of the tools used to administer funds within the household, and its members may use professional assistance when setting their financial objectives.

In Poland, the financial advisory industry was formed as a result of economic changes occurring after the switch from planned economy, and raising demand on the mortgage loan market, however - unlike in developed countries such as Germany or Great Britain - Polish financial advisory services are in early stages of development and the profession itself is not regulated, nor does it require any type of certification. As a result, the scope of services provided by native financial advisory institutions is often limited to credit brokerage - cash and mortgage credits sales - which reflects clearly in sales results presented by Financial Advisory Companies Association (Związek Firm Doradztwa Finansowego - ZFDF) (Table 3).

Table 3. Total value of mortgage loans, cash credits and investment products sold by ZFDF members in IV quarter of 2015 and I quarter of 2016 (mln PLN)

\begin{tabular}{|l|r|r|r|r|r|c|}
\hline \multirow{2}{*}{\multicolumn{1}{|c|}{ Company name }} & \multicolumn{2}{c|}{ Mortgage loans } & \multicolumn{2}{c|}{ Cash credits } & \multicolumn{2}{c|}{ Investments } \\
\cline { 2 - 7 } & IVQ 2015 & IQ 2016 & IVQ 2015 & IQ 2016 & IVQ 2015 & IQ 2016 \\
\hline Open Finance SA + Home Broker & $1,425.00$ & $1,347.00$ & 215.00 & 241.00 & $1,194.00$ & 641.00 \\
\hline Expander & $1,286.50$ & $1,190.40$ & 107.03 & 125.56 & 126.90 & 87.57 \\
\hline Notus Doradcy Finansowi & 565.57 & 531.07 & 72.97 & 83.35 & 0.51 & 0.17 \\
\hline Aspiro & 507.39 & 275.08 & 26.52 & 30.70 & - & - \\
\hline Gold Finance & 180.44 & 176.24 & 15.59 & 15.88 & - & - \\
\hline Doradcy 24 & 49.40 & 44.50 & 2.70 & 2.70 & - & - \\
\hline Total & $4,014.30$ & $3,564.29$ & 439.81 & 499.19 & - & - \\
\hline
\end{tabular}

Source: on basis of ZFDF data presented on http://www.zwiazek-doradcow.org.

According to AMRON-SARFIN, in the report in IV quarter of 2015 the total amount of paid-out mortgage loans was $10.58 \mathrm{mln}$ PLN. In this period, an increase of mortgage loans sales in terms of credit value was noted, in comparison to previous quarters. In the first quarter however, the total amount of extended loans was $9.43 \mathrm{mln}$ PLN. This implies that the importance of financial advisors in banking channels of distribution is systematically increasing.

Undeniably, including financial advisor in the household financial planning process brings quantifiable benefits to its members. Waliszewski (2014, pp. 216-217) quotes i.e.: more effective expenditure of resources, professional income and spending planning, personal budget management, building intentional habit and long-term accumulation of capital, creating capital buffer for fortuitous events and exceeding spending, creating investment awareness about risks involved in specific financial instruments, tax optimization for transactions made within scope of household financial planning, including intergenerational transfer of assets, as well as assistance with optimal management of liabilities. Despite financial advisory being a new segment on financial market, it is an extremely elaborate one. The surging importance of financial planners can be 
noted not only in increased mortgage loans sales, but also cash credits and investment products, which in the low interest rate environment are becoming increasingly attractive. The most popular products offered by financial advisory institutions are structured products, regular savings instruments and casualty insurances and, as of late, real estate property investments, e.g. apartment housing, condohotels.

\section{Conclusion}

Households are aiming to satisfy their needs on both individual and collective levels. In order to achieve their goal, they increase their demand for professional financial planning services. It is mainly a result of overload of information coming from financial markets, which - in case of insufficient financial literacy - may lead us to making unfavorable investments. Therefore the main goal of financial planner is to protect the household assets and to accomplish those investment goals that will ensure financial stability. Before making a proposal of financial service, each advisor is conducting appropriate market analysis and the plan that they recommend takes into account the financial needs of the household, and is pointing out the direction of their fulfillment both in short and in long term. The financial advisory services are provided by private enterprise as well as employees of various financial institutions, which allows advisors to act in the name of one individually chosen institution or to independently present offers of various organizations.

\section{References}

Agnew, J.R., Bateman, H., Thorp, S. (2013). Financial Literacy and Retirement Planning in Australia. University of South Florida, Scholar Commons, 6 (2).

Arthur, C. (2012). Financial literacy education, Neoliberalism, the consumer, the citizen. Rotterdam, Boston, Taipei: Sense Publishers.

Atkinson, A., Messy, F. (2012). Measuring Financial Literacy: Results of the OECD / International Network on Financial Education (INFE) Pilot study. OECD Working papers on Finance, insurance and private pensions, No. 1. OECD Publishing.

Bodie, Z., Merton, R.C. (2003). Finanse. Warszawa: Wydawnictwo Ekonomiczne SA.

Brandon, E.D., Welch, H.O. (2009). The History of Financial Planning: The Transformation of Financial Services. New Jersey: John Wiley \& Sons.

Bywalec, C. (2009). Ekonomika i finanse gospodarstw domowych. Warszawa: Wydawnictwo Naukowe PWN.

Campbell, J.Y. (2006). Household Finance. The Journal of Finance, 56.

Ciechanowicz, J. (2010). Trzy etyki heraklitejskie, Etyka wielkich cywilizacji. Tom I. Nowy Jork: Polis Guide Publishing.

Drabik, I., Smyczek, S. (2007). Funkcjonowanie mikropodmiotów - przedsiębiorstw i gospodarstw domowych - na jednolitym europejskim rynku. Katowice: Wyższa Szkoła zarządzania marketingowego i Języków Obcych w Katowicach.

Harrison, E.F. (1995). The Managerial Decision Making Proces. Boston: Houghton Mifflin.

Hens, T., Bachmann, K. (2010). Psychologia rynku dla doradców finansowych. Warszawa: CeDeWu.

Jajuga, K. (2008). Inwestycje w osobistym planowaniu finansowym. In: K. Jajuga, T. Jajuga (eds.), Inwestycje. Warszawa: Wydawnictwo Naukowe PWN.

Khaneman, D., Tversky, A. (2000). Choices, values and frames. New York: Cambridge University Press.

Komorowski, J. (2001). Planowanie finansowe w przedsiębiorstwie. Gdańsk: Wydawnictwo ODDK. 
Korenik, D. (2006). Bank i jego ustugi w dobie „rewolucji finansowej”. In: D. Korenik (ed.), Innowacyjne ustugi banku. Warszawa: Wydawnictwo Naukowe PWN.

Lusardi, A., Mitchell, O.S. (2011). Financial literacy and retirement planning in the United States. Journal of Pension Economics and Finance. Cambridge University Press, 10.

Nowak, E. (1995). Dynamiczne modele zarządzania finansami w przedsiębiorstwie. Warszawa: PRET.

Robbins, S.P. (2005). Skuteczne podejmowanie decyzji. Warszawa: PWE.

Shefrin, H.M., Thaler, R.H. (1988). The Behavioral Life-Cycle Hypothesis. Economic Inquiry, ABI/INFORM Complete, October.

Skorwider, J. (2011). Gospodarstwo domowe jako podmiot usług doradztwa finansowego w Polsce. Zeszyty Naukowe Wyższej Szkoły Bankowej we Wrocławiu, 25.

Siegel, R. (2010). Personal Finance. Washington: Saylor Fundation.

Stiftung, K.A. (2014). Rola edukacji finansowej w ograniczeniu wykluczenia finansowego. Gdańsk: Instytut Badań nad Gospodarką Rynkową.

Świecka, B. (2009). Niewypłacalność gospodarstw domowych. Przyczyny-skutki-przeciwdziałanie. Warszawa: Difin.

Tullio J., Mario, P. (2011). Investment in financial literacy and saving decisions. Centre of Financial Studies, Goethe University, Working Paper no. 2011/07.

Tyszka, T. (2010). Decyzje. Perspektywa psychologiczna i ekonomiczna. Warszawa: Scholar.

Waliszewski, K. (2011). Doradztwo finansowe w Polsce. Warszawa: CeDeWu.pl.

Waliszewski, K. (2012). Europejskie Standardy Doradztwa Finansowego w Polsce. I. Pyka, J. Cichorska (eds), Finanse w niestabilnym otoczeniu - dylematy i wyzwania (pp. 479-490). Zeszyty Naukowe Uniwersytetu Ekonomicznego w Katowicach.

Waliszewski, K. (2014). Planowanie finansów osobistych (zarządzanie finansami osobistymi) z udziałem doradców finansowych - znaczenie dla gospodarstw domowych i gospodarki. Problemy Zarządzania, Współczesne wyzwania w bankowości i finansach, 12/1 (4/48).

Wilkinson, N. (2008). An introduction to behavioral economics. New York: Palgrave Macmillan.

Xelion compliant with European standards of financial advisory. Press conference materials, November 22 nd 2005 , Warsaw.

Zaleśkiewicz, T. (2012). Psychologia ekonomiczna. Warszawa: Wydawnictwo Naukowe PWN.

Związek Banków Polskich. Ogólnopolski raport o kredytach mieszkaniowych i cenach transakcyjnych nieruchomości. Raport Amron-Sarfin 4/2015, Centrum Amron, Warszawa, 2016.

Związek Firm Doradztwa Finansowego. Retrieved from: http://www.zwiazek-doradcow.org.

\section{Cytowanie}

Mitek, Ł.M. (2016). Household financial planning with financial advisory assistance. Współczesne Finanse. Teoria i Praktyka, 1 (1), 73-82. DOI: 10.18276/wf.2016.1-07. 